\title{
Article
}

\section{Brazing of selected heat-resisting alloys using Ni-Pd filler metal}

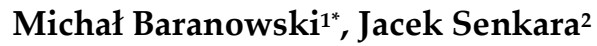 \\ ${ }^{1}$ ŁUKASIEWICZ Research Network - Institute of Precision Mechanics, Poland \\ 2 Warsaw University of Technology, Poland \\ Prof. Jacek Senkara; jsenkara@wip.pw.edu.pl; \\ * Correspondence: Michał Baranowski, Ph.D.; michal.baranowski@imp.edu.pl
}

Received: 15.07.2019; Accepted: 30.09.2019

\begin{abstract}
Pd is a component of some advanced nickel filler metals designed for brazing heat-resisting alloys in order to improve their wettability and to enhance both corrosion resistance and plasticity of the joints. The joints of Inconel 625, Inconel 718, Hastelloy X, and 410 martensitic stainless steel were prepared by vacuum brazing with NiPd36Cr10BSi filler alloy. Complex structures of the joints were tested. It was revealed the displacement of interfaces from their initial positions in the course of brazing along with active action of $\mathrm{Cr}$, Mo and $\mathrm{Nb}$ (for Inconel 718 alloy) in the formation of interstitial layers.
\end{abstract}

Keywords: vacuum brazing; Ni-Pd filler metal; heat-resisting alloys; structure of joints

\section{Introduction}

Nickel alloys and some special stainless steels along with aluminum, titanium and composite materials are widely used for the construction of contemporary aircraft engines. Some of them are characterized by the low densities and possessing the required mechanical properties. In some sections of engines where the operating temperature exceeds $500{ }^{\circ} \mathrm{C}$ it is necessary to use heat-resisting and high-temperature creep resisting alloys of superior performance in elevated temperatures, which include nickel-based superalloys $[1 \div 3]$.

The production of parts designed to work in hot sections of engines requires advanced methods of materials processing, which include hard and high temperature brazing in vacuum. In the aviation industry, copper-based, silver-based, gold or nickel-based fillers are used for that purpose to join nickel superalloys and special stainless steels $[2,4,5]$. The most important filler metals for brazing nickel superalloys are $\mathrm{NiCr}$-base alloys which require brazing temperatures above $900{ }^{\circ} \mathrm{C}[6 \div 8]$. Palnicro $36 \mathrm{M}$ braze falls into this category possessing in addition to nickel and chromium $36 \%$ palladium. It is believed that the addition of this element improves wettability of substrates and positively affects corrosion resistance and the plasticity

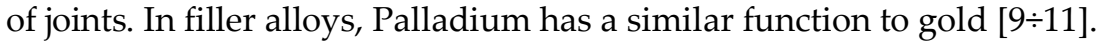

Palladium forms solid solutions with nickel and chromium - basic components of filler alloys, however its impact onto the structure of the building joints is more complex. The paper presents results of comparative study of the interaction of Palnicro 36M braze with several heat-resisting substrate materials applied in aviation technology.

\section{Materials and Methods}

Four different variants of Palnicro 36M braze with the following base materials were tested in the study: Inconel 718, Inconel 625 and Hastelloy X nickel alloys, and martensitic stainless steel 410. Chemical compositions of all materials mentioned above are presented in table I and table II.

Table I. Chemical composition of selected base materials [wt.\%] [12,13]

\begin{tabular}{cccccccccccccccccc}
\hline & $\mathbf{N i}$ & $\mathbf{C r}$ & $\mathbf{F e}$ & $\mathbf{M o}$ & $\mathbf{C o}$ & $\mathbf{W}$ & $\mathbf{C}$ & $\mathbf{M n}$ & $\mathbf{S i}$ & $\mathbf{C u}$ & $\mathbf{P}$ & $\mathbf{B}$ & $\mathbf{S}$ & $\mathbf{A l}$ & $\mathbf{T i}$ & $\mathbf{N b}+\mathbf{T a}$ \\
\hline Inconel 718 & 52.5 & 19 & 17 & 3.05 & 1 & - & 0.08 & 0.35 & 0.35 & 0.30 & 0.015 & 0.006 & 0.015 & 0.6 & 0.9 & 5.125 \\
Inconel 625 & 58 & 21.5 & 5 & 9 & 1 & - & 0.1 & 0.5 & 0.5 & - & 0.015 & - & 0.015 & 0.4 & 0.4 & 3.65 \\
Hastelloy X & 47 & 22 & 18 & 9 & 1.5 & 0.6 & 0.1 & 1 & 1 & 0.50 & 0.040 & 0.008 & 0.030 & - & - & - \\
$\quad$ SS 410 & - & 12.5 & Bal. & - & - & - & 0.15 & 1 & 1 & - & 0.04 & - & 0.03 & - & - & - \\
\hline
\end{tabular}


Table II. Chemical composition of Palnicro 36M filler metal [wt.\%] [14]

\begin{tabular}{cccccccc}
\hline & Pd & Ni & Cr & B & Si & $\begin{array}{c}\text { Solidus } \\
\text { temperature }\left[{ }^{\circ} \mathrm{C}\right]\end{array}$ & $\begin{array}{c}\text { Liquidus } \\
\text { temperature }\left[{ }^{\circ} \mathrm{C}\right]\end{array}$ \\
\hline Palnicro 36M & 36 & 50 & 10.5 & 3 & 0.5 & 820 & 960 \\
\hline
\end{tabular}

Substrates for the tests had the form of $25 \times 25 \mathrm{~mm}$ plates made of $1 \mathrm{~mm}$ thick sheets. The sheets were not machined but used as supplied. Since the wettability depends in some sense from the surface geometry, surface roughness parameters were measured which results are presented in table III. They do not significantly differ. Braze foil of $0.05 \mathrm{~mm}$ thickness was used in vacuum brazing. The foil was cut to form rectangular shape samples of the same weight and placed over the substrates (Fig. 1). All materials were washed in acetone using an ultrasonic cleaner before processing.

Table III. Results of surface roughness measurements of substrates

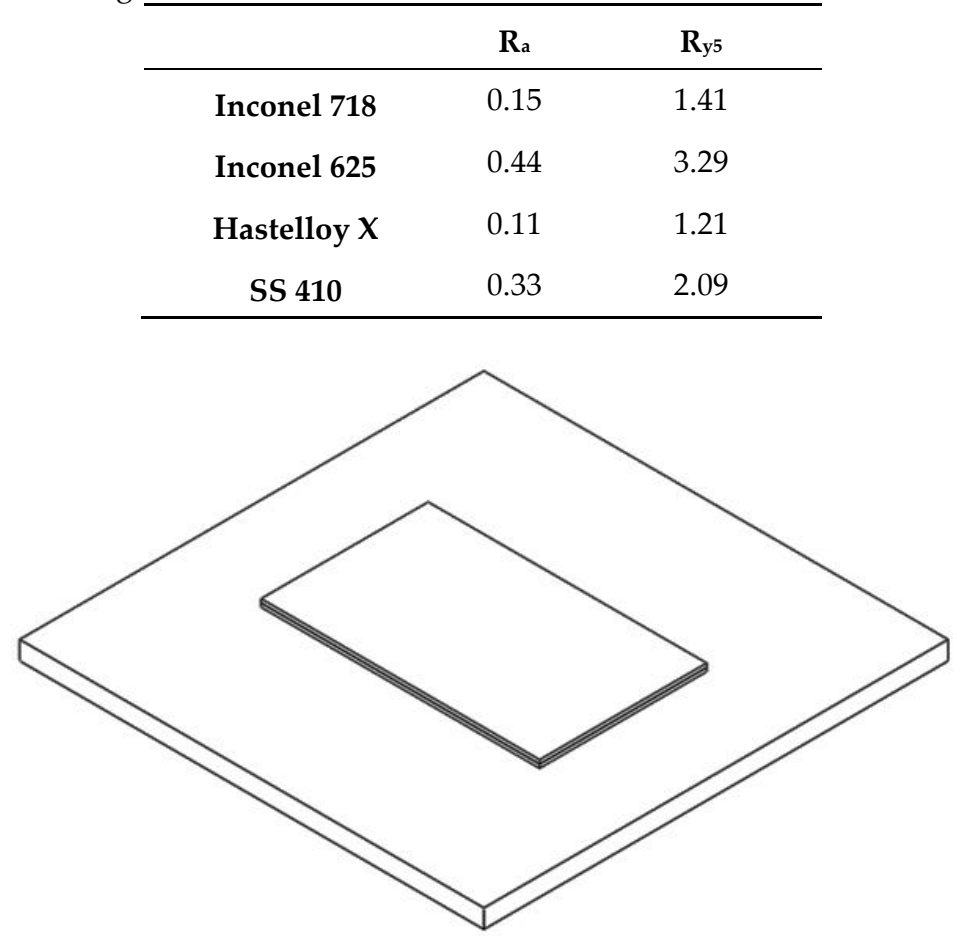

Fig. 1. Scheme of samples for testing the interaction between braze metal and substrates

Such prepared samples were placed to the laboratory vacuum furnace, heated up to $995^{\circ} \mathrm{C}$ and held for $10 \mathrm{~min}$ in the $10^{-3} \mathrm{mbar}$ vacuum. After the cooling structural studies of joints were performed. The samples were cut perpendicular to the joints and metallographic specimens were made. Keyence VHX 5000 digital optic microscope and Jeol JSM-7600F scanning electron microscope were used to characterize the joints structures. The distribution of elements in the interstitial zones was examined by EDS.

\section{Research results}

Figure 2 shows microscopic images of specimens perpendicular to the substrate surface plane at the wetting perimeter of braze metals droplet after its solidification and the base material. Part of surface not covered by filler visible on photos allows to determine the displacement of the solid-liquid phase contact line from its original position before the process.

For Inconel 625-Palnicro 36M and Hastelloy X-Palnicro 36M joints, the solid-liquid interfaces coincide with the surfaces of the non-wetted substrates. In the other two cases, for Inconel 718 and for stainless steel 410 , the shift of the direct solid-liquid phase interaction line is clearly visible. 


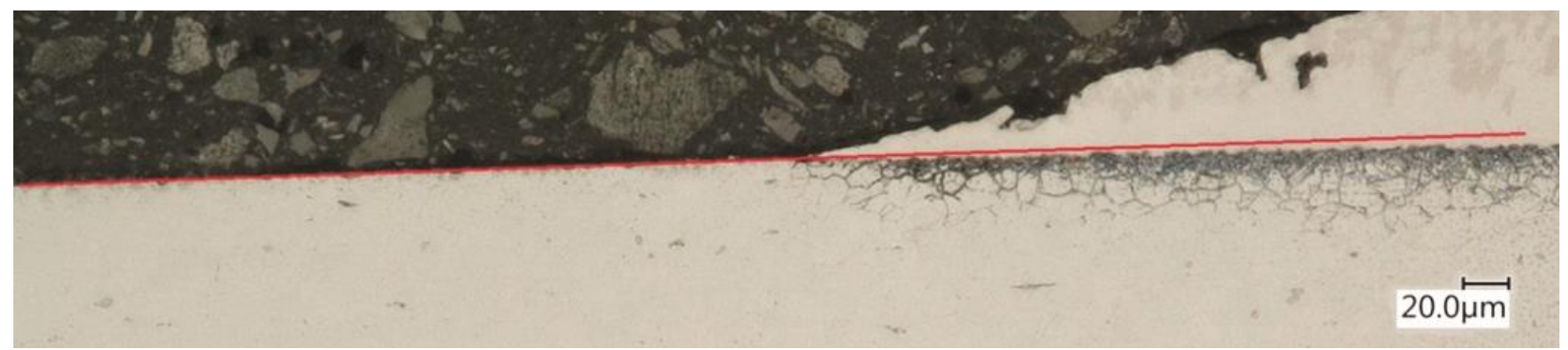

(a)

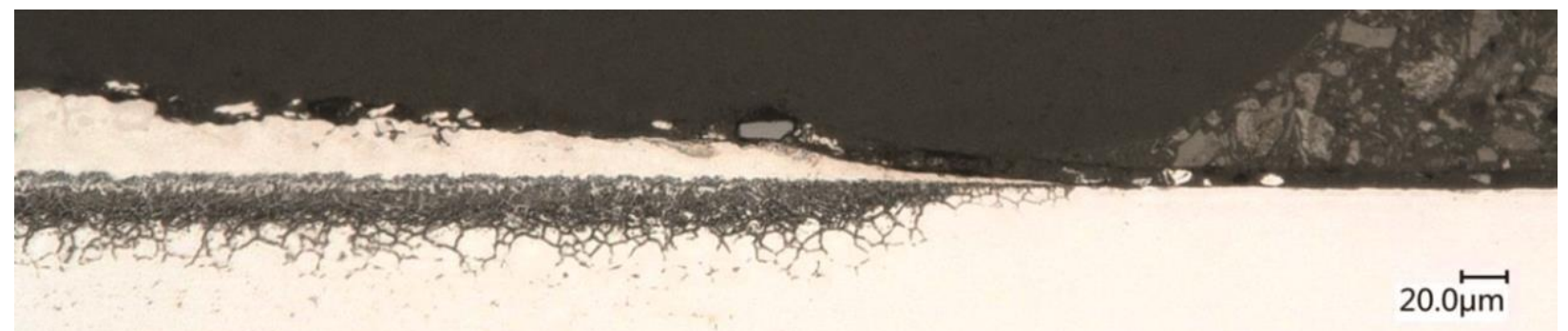

(b)

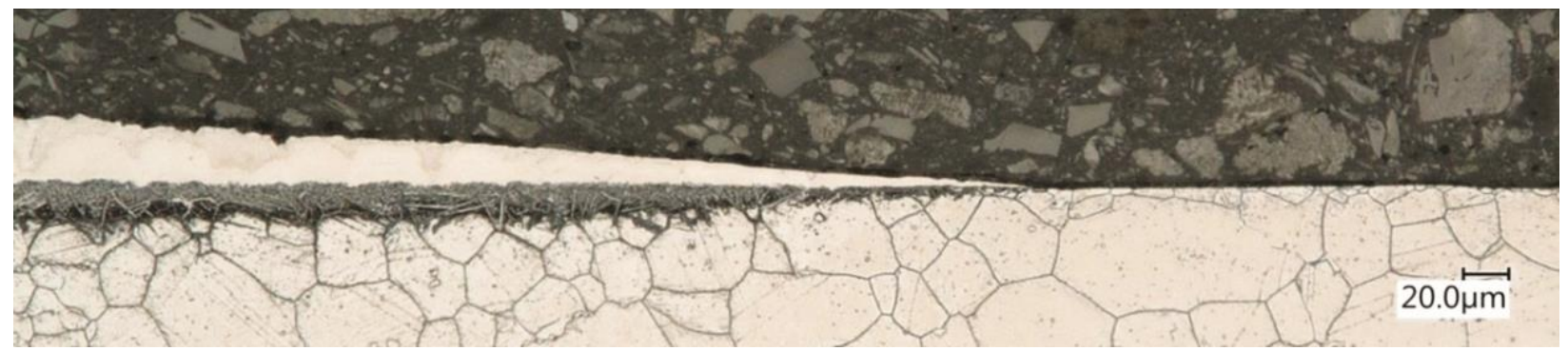

(c)

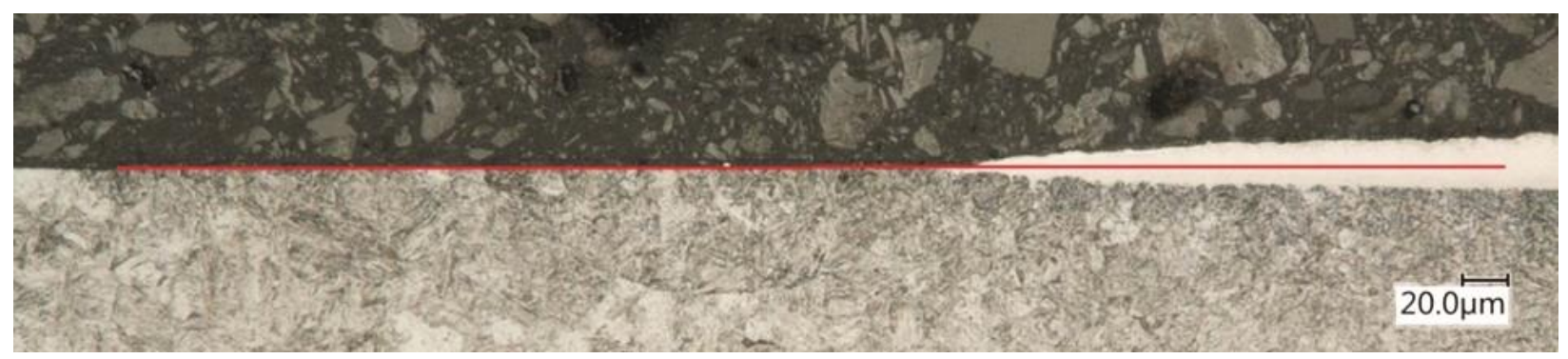

(d)

Fig. 2. The structure in the area of the interface Palnicro 36M braze with: a) Inconel 718, b) Inconel 625, c) Hastelloy $\mathrm{X}$ alloy and d) 410 steel close to the wetting perimeter

A multi-phase structures with numerous precipitates were created in each of the tested variants during solid-liquid interaction in the brazing temperature. The effects of such interaction are visible on both the braze side and the substrates side. Complex structures were formed in the direct interaction zone as a result of mutual diffusion of elements and/or grain boundary penetration of liquid phase into the substrate. SEM images of these structures and surface distribution of elements throughout the contact zone are shown in Figures $3 \div 6$. 

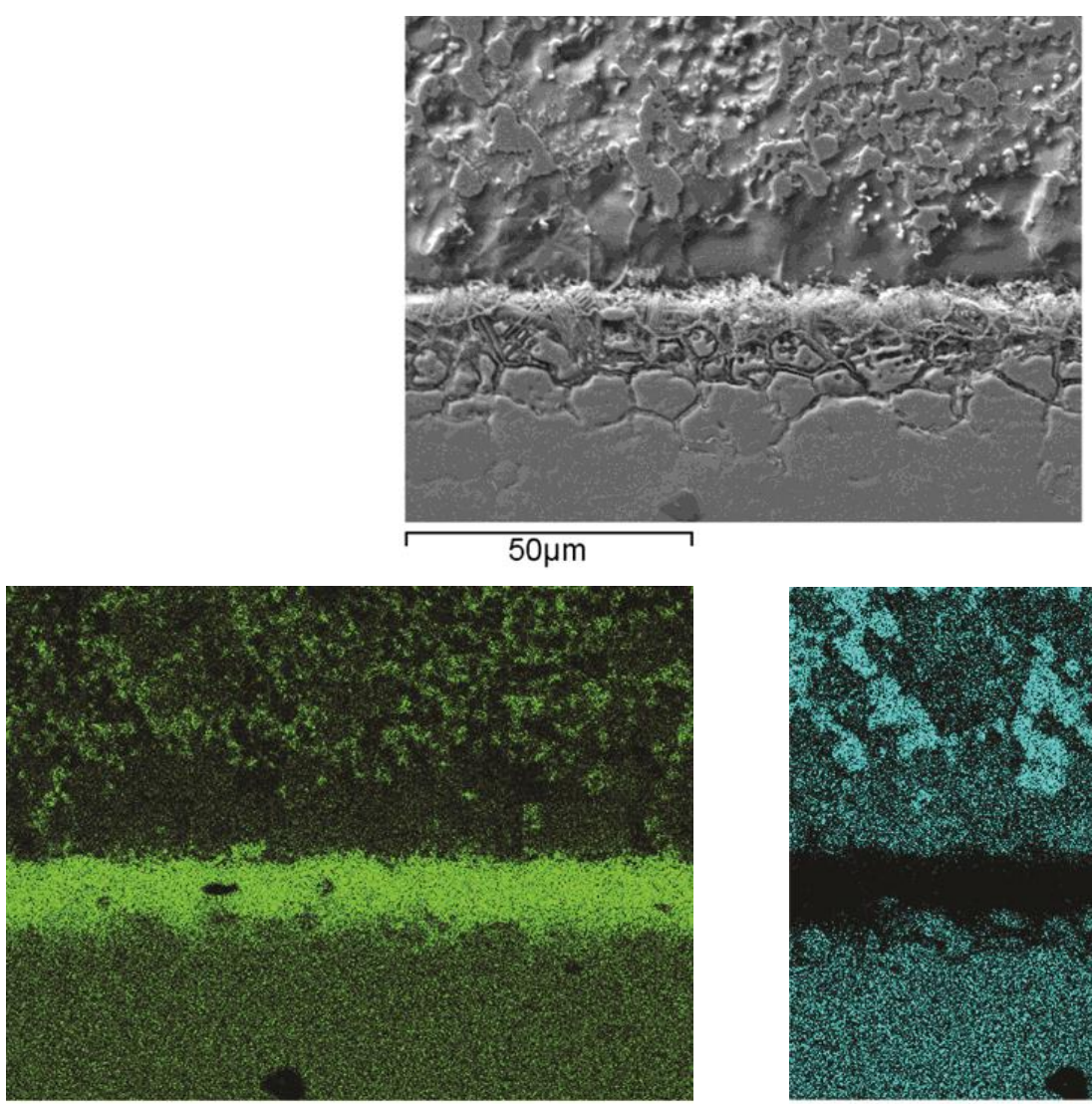

Cr Ka1
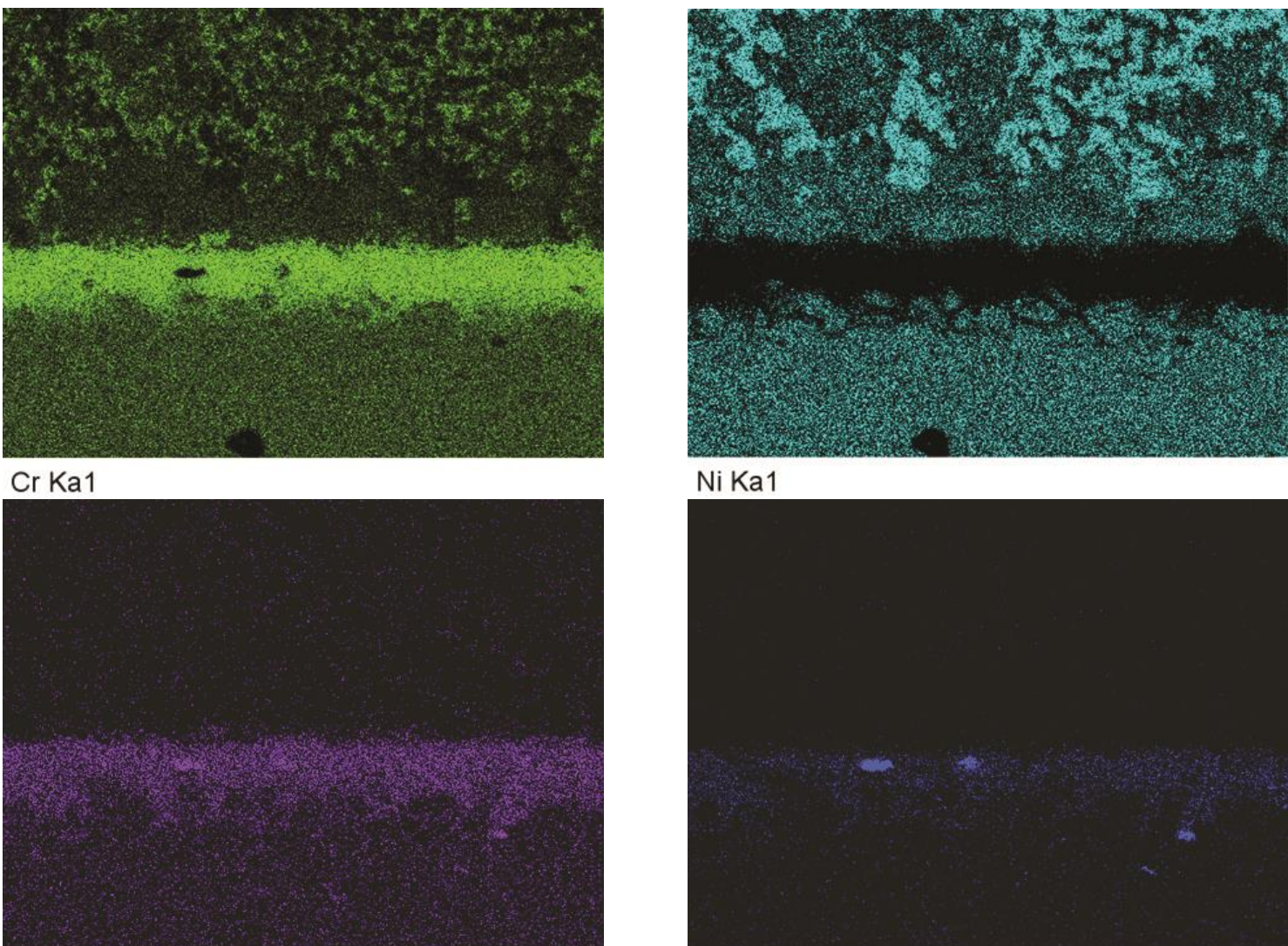

Mo La1
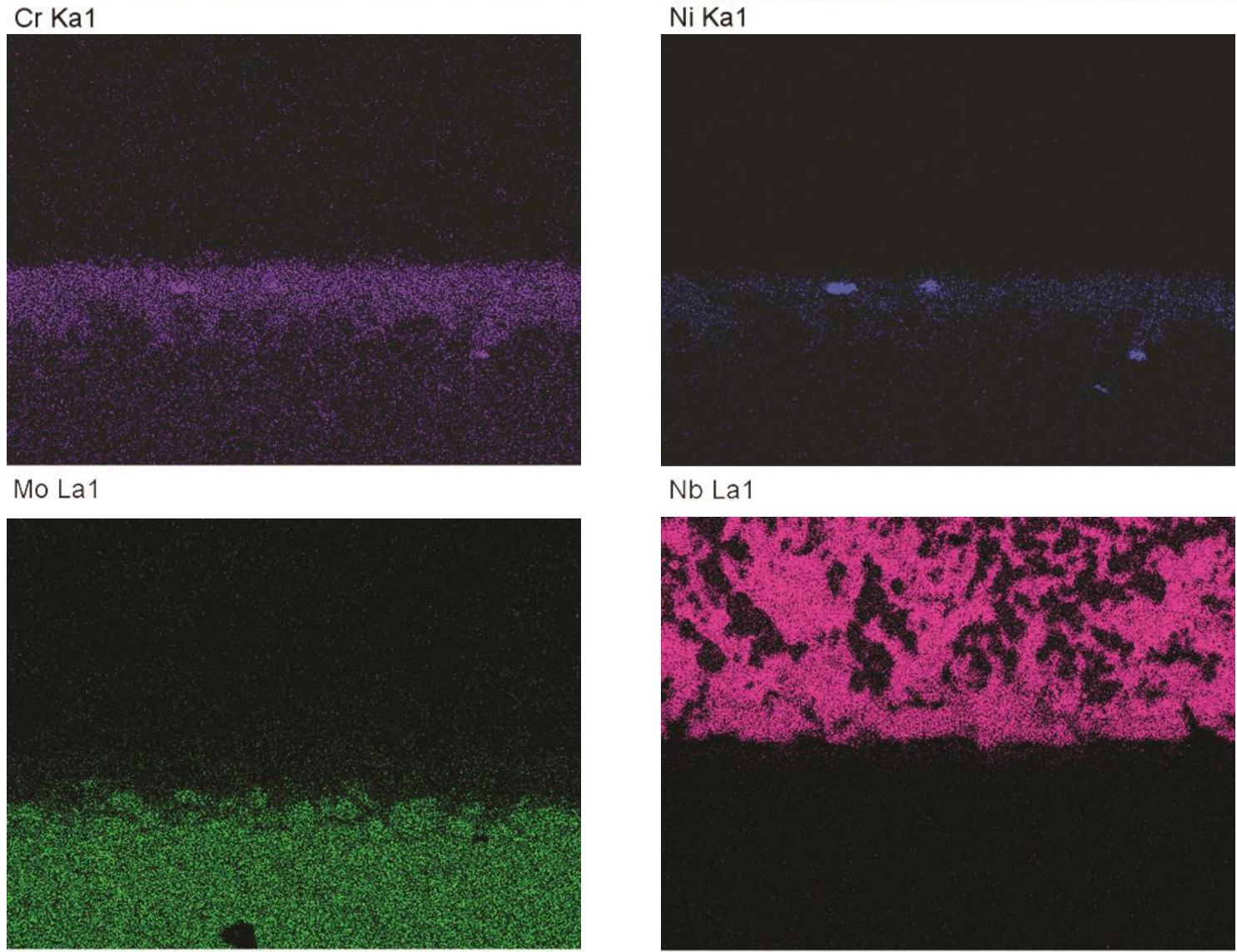

$\mathrm{Fe} \mathrm{Ka} 1$

$\mathrm{Nb}$ La1

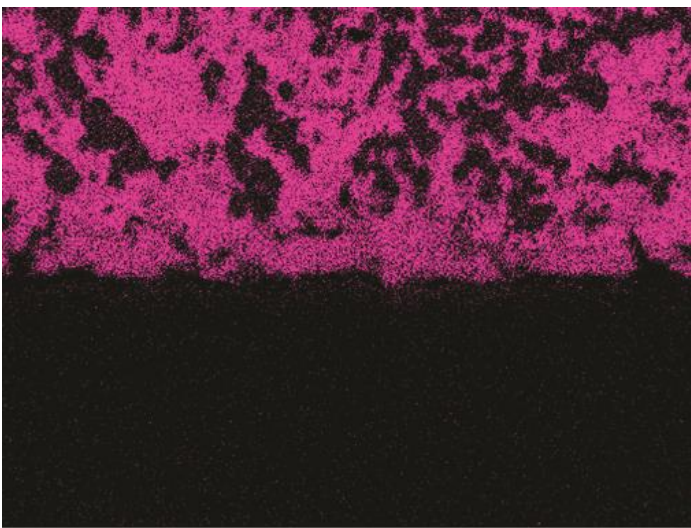

Pd La1

Fig. 3. SEM image and surface distribution of elements in the Inconel 718-Palnicro 36M joint

The zone of interaction between solid and liquid phase in the Inconel 718-Palnicro 36M combination indicates a significant increase in chromium, molybdenum and niobium while the iron and nickel content dropped. Palladium is found in the filler bulk only. 


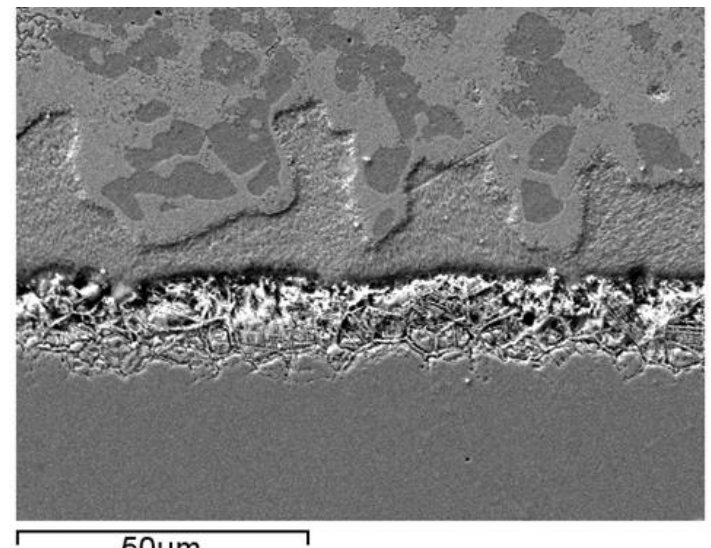

$50 \mu \mathrm{m}$

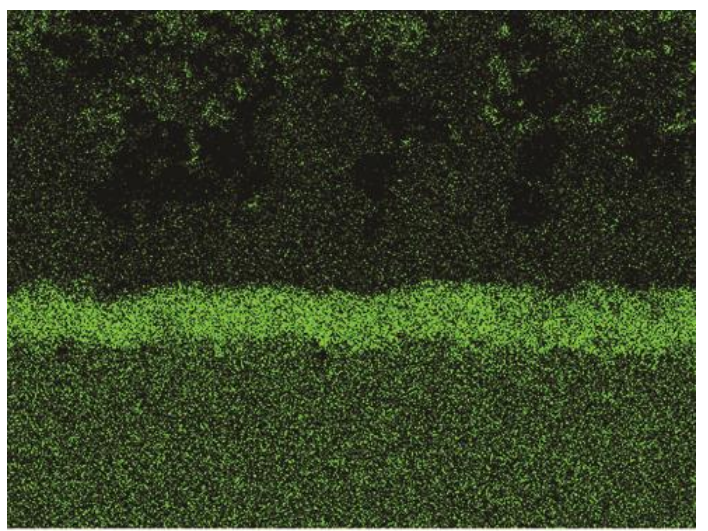

Cr Ka1
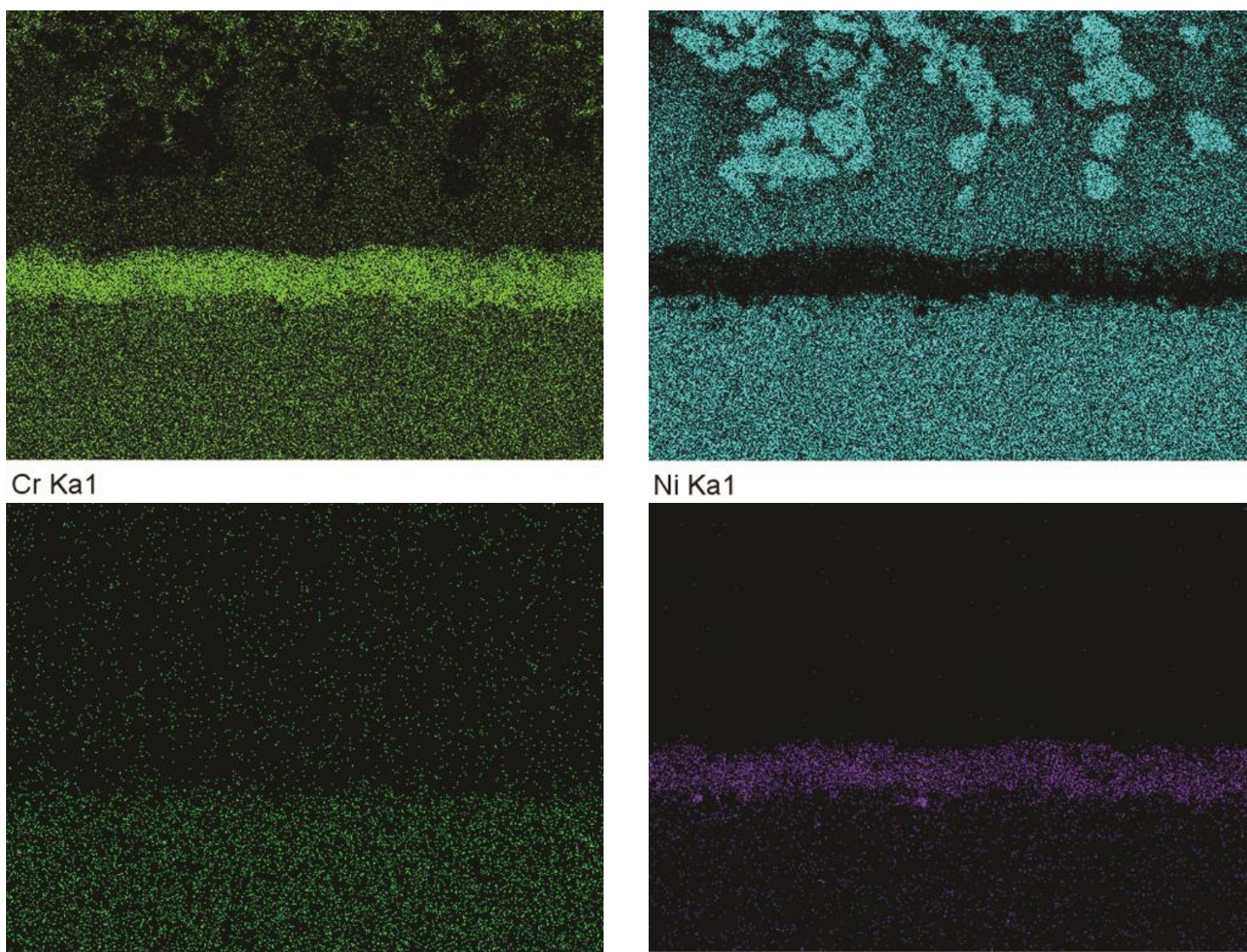

$\mathrm{Fe} \mathrm{Ka1}$

Ni Ka1
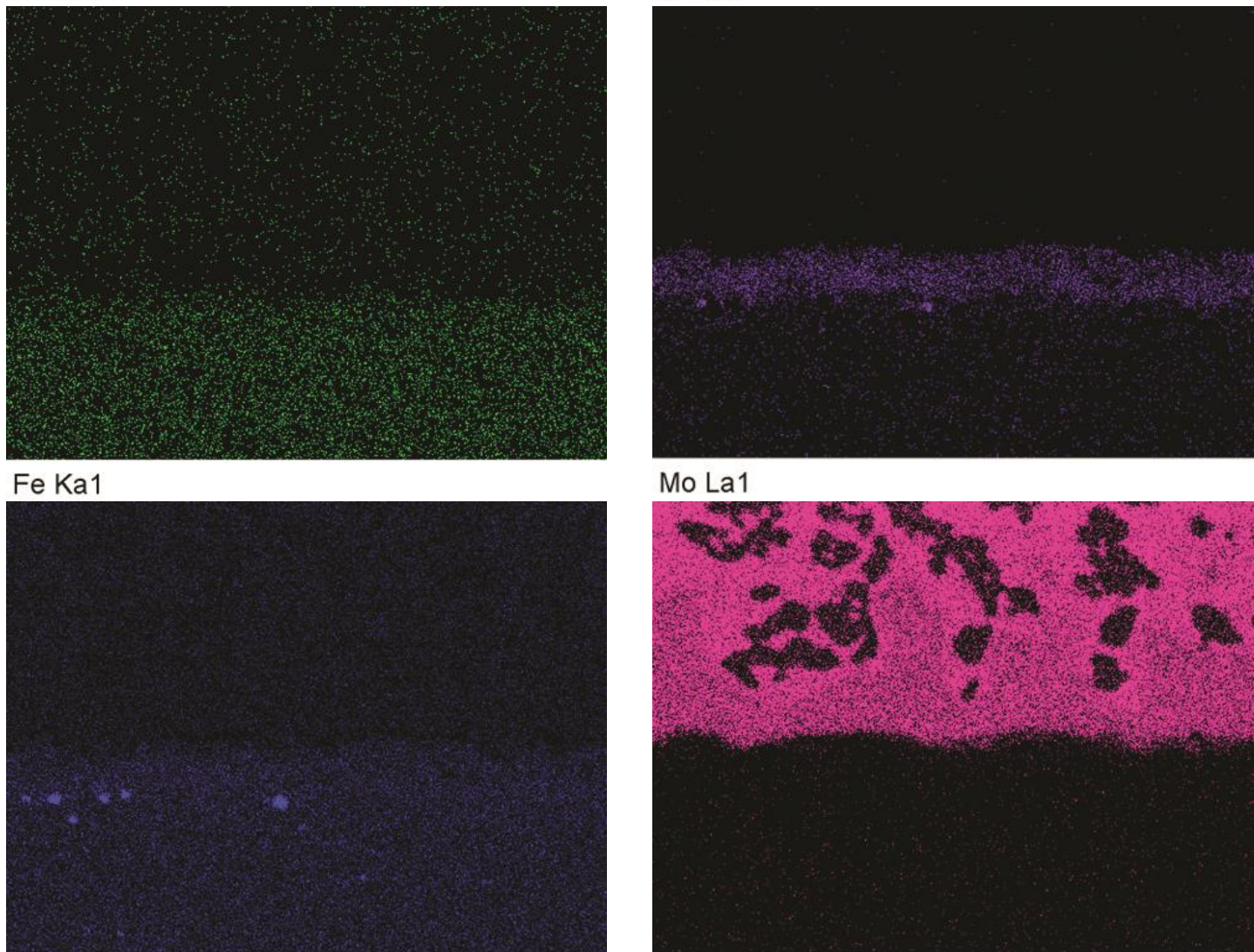

$\mathrm{Nb}$ La1

Mo La1

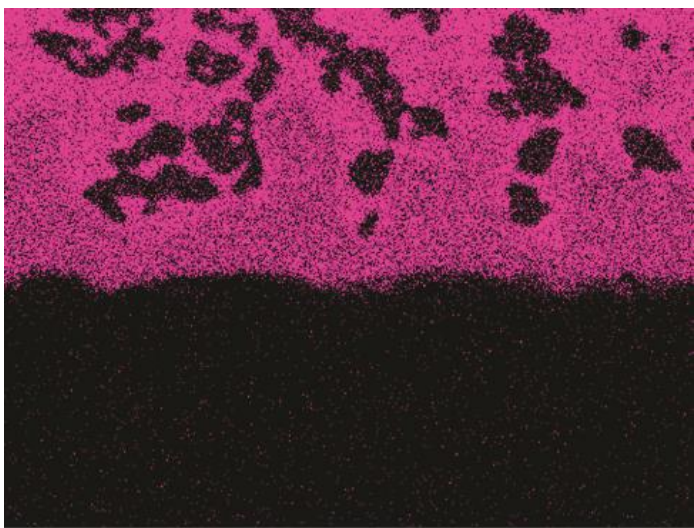

Pd La1

Fig. 4. SEM image and surface distribution of elements in the Inconel 625-Palnicro 36M joint

Similarly, in the Inconel 625-Palnicro 36M contact zone, the amount of chromium and molybdenum increased in the braze-substrate transition layer but the iron and nickel content was reduced. Palladium is inactive and distributed in the matrix of the filler metal. 


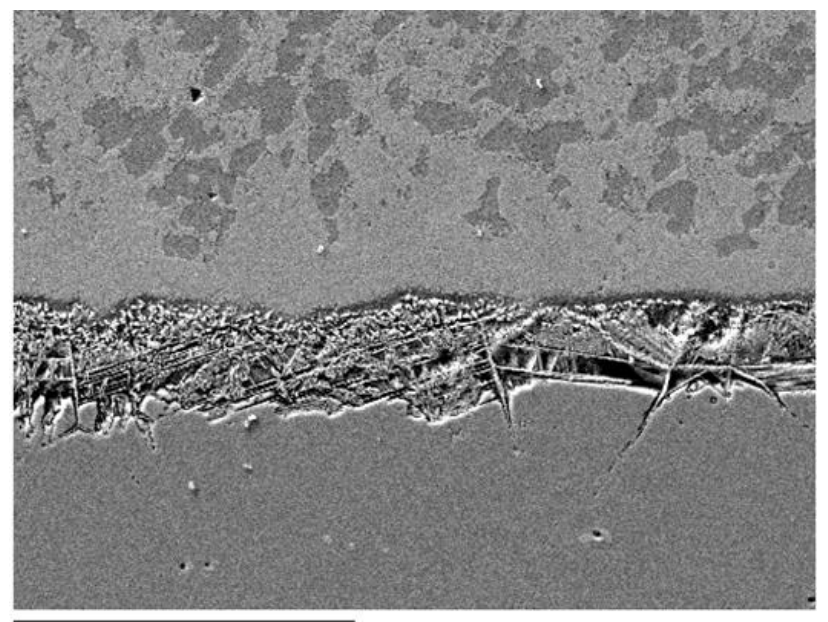

$50 \mu \mathrm{m}$

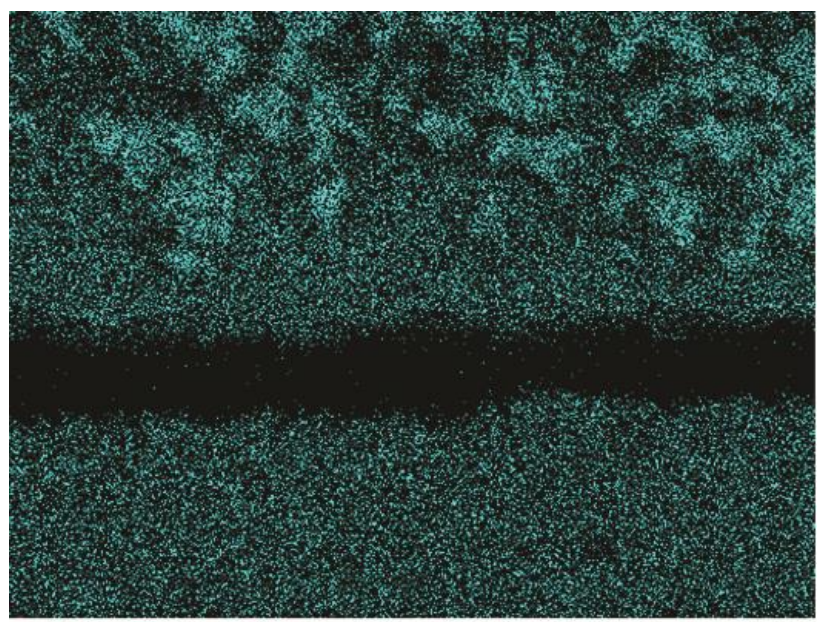

Ni Ka1

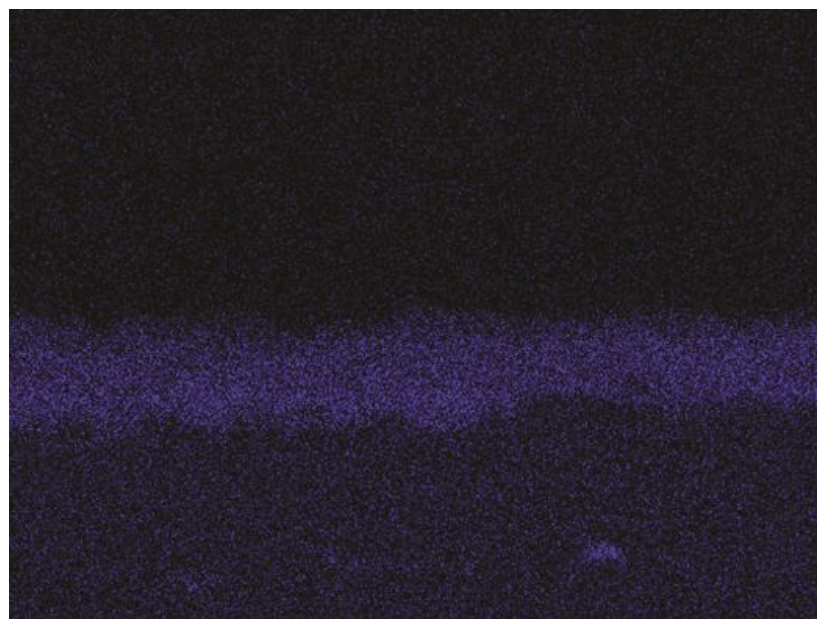

Mo La1

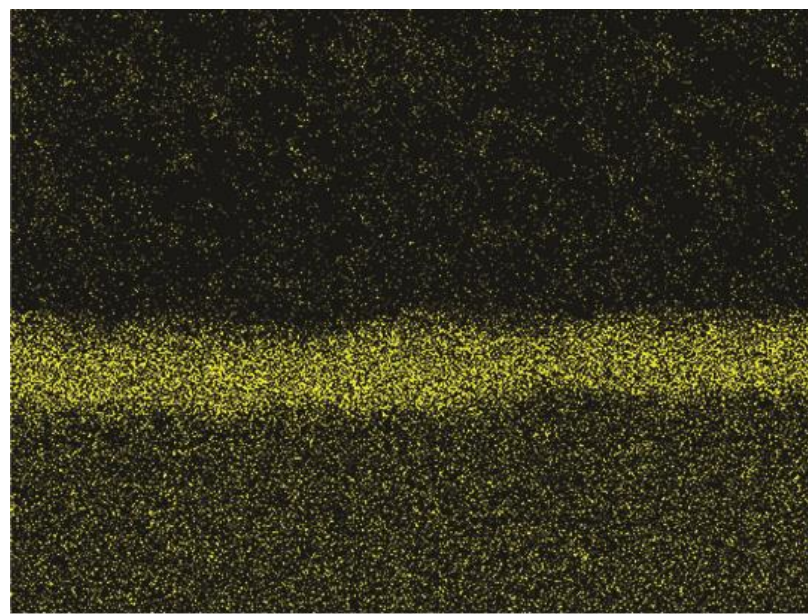

Cr Ka1

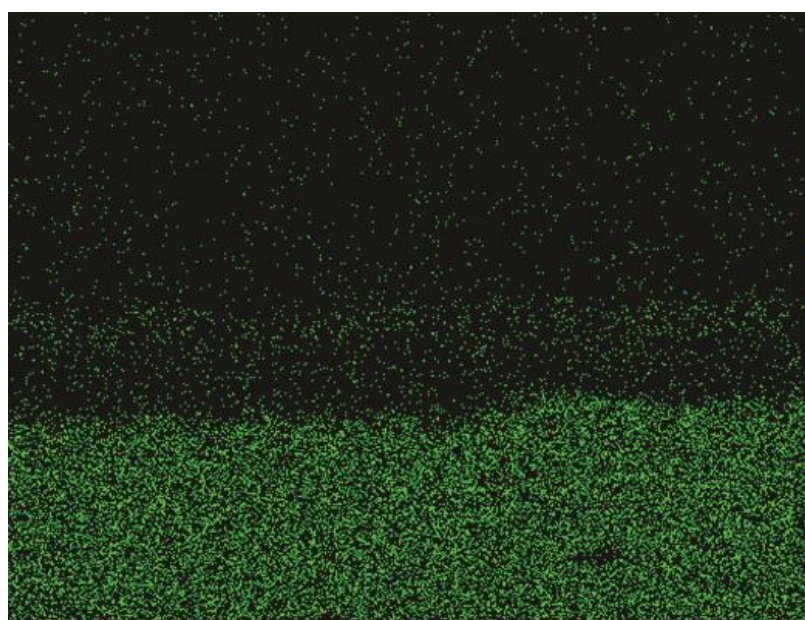

Fe Ka1

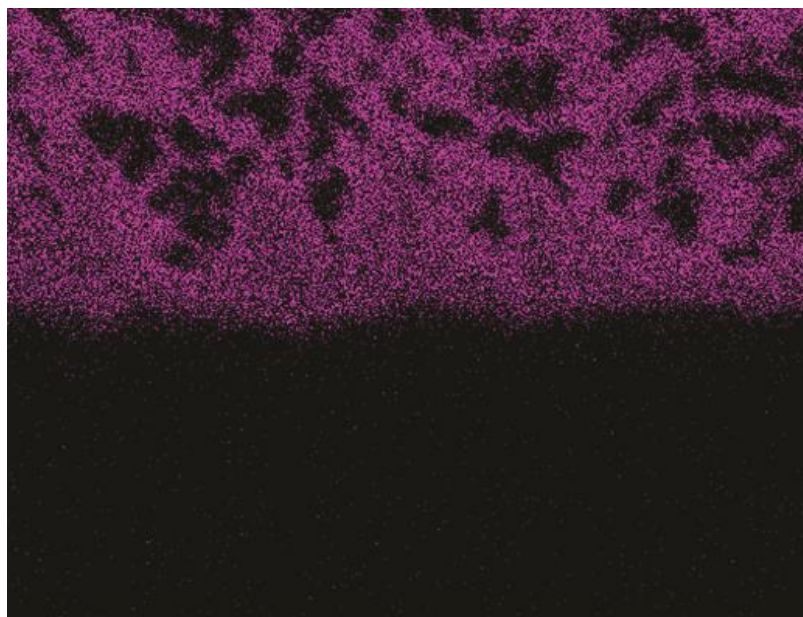

Pd La1

Fig. 5. SEM image and surface distribution of elements in the Hastelloy X-Palnicro 36M joint

The increase in chromium and molybdenum content in the zone of direct solid-liquid phase interaction is also visible for the Hastelloy $\mathrm{X}-$ Palnicro $36 \mathrm{M}$ case. As in the previous variants, a decrease in content was noted for iron and nickel while palladium occurs also evenly distributed in the braze.

The composition of stainless steel 410 does not contain molybdenum, which is active in the transition zone of filler-substrate joints in all other variants. The images in figure. 6 indicate that the transition zone in the combination of stainless steel $410-P a l n i c r o 36 \mathrm{M}$ is build of iron and chromium. As in other variants, a reduction in nickel content and the occurrence of palladium in the filler metal are noticed. 

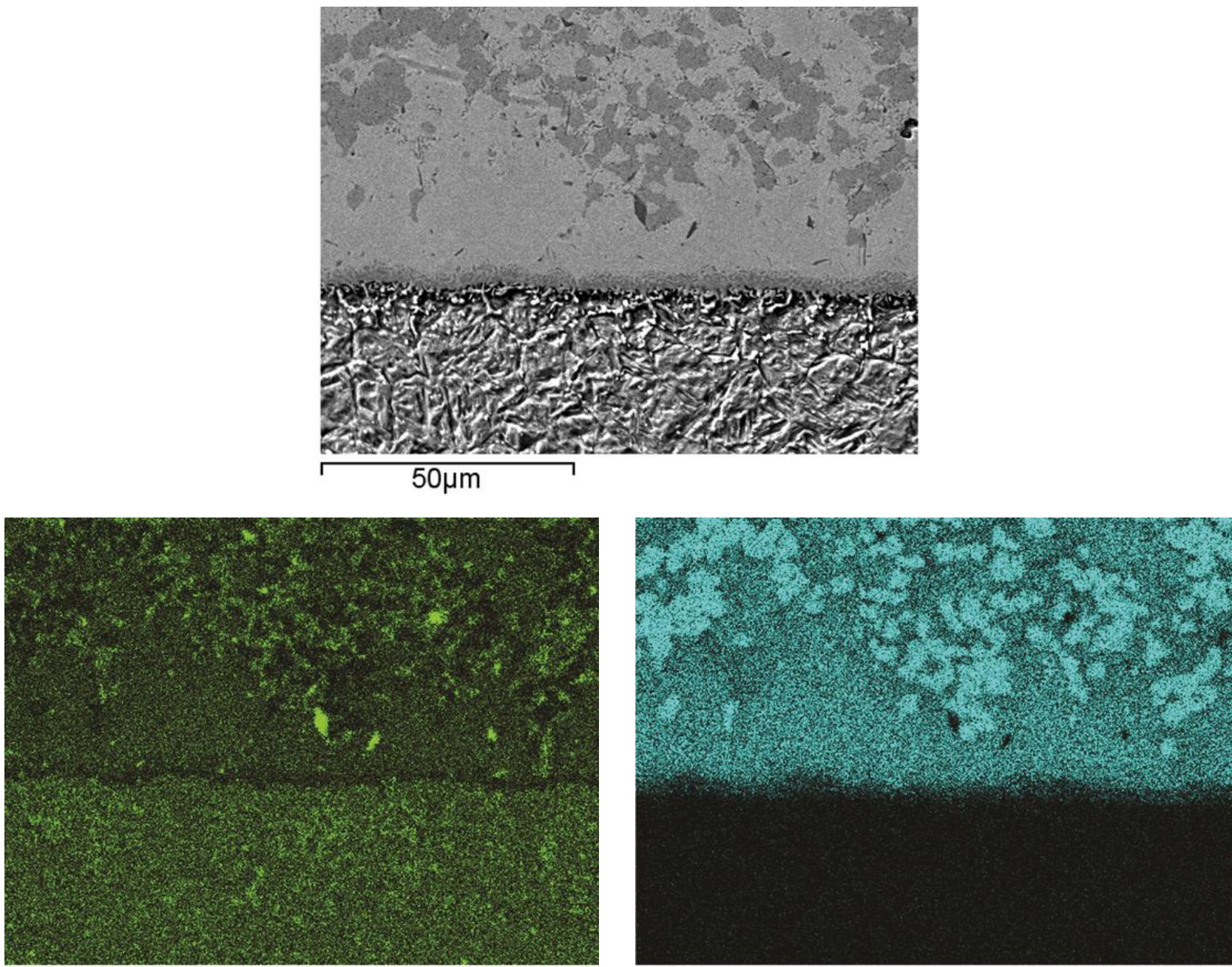

Cr Ka1

Ni Ka1
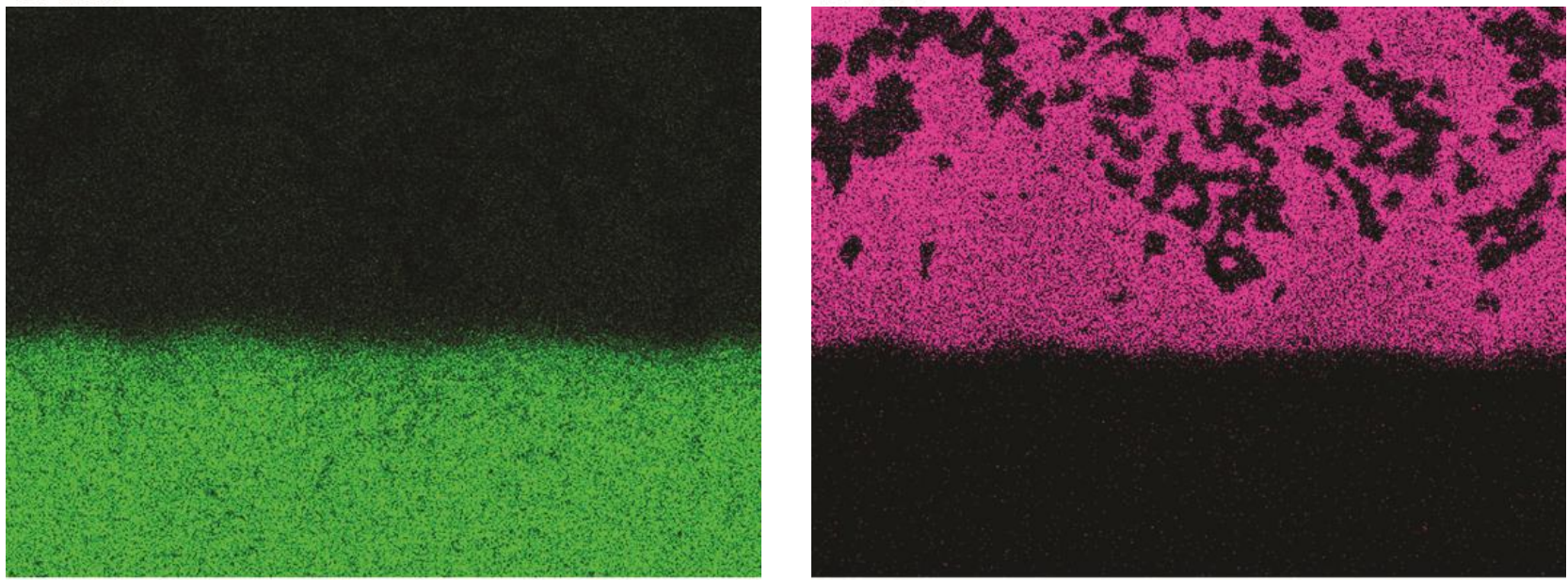

$\mathrm{Fe} \mathrm{Ka1}$

Pd La1

Fig. 6. SEM image and surface distribution of elements in the stainless steel 410 - Palnicro 36M joint

\section{Summary}

Complex structures are formed as a result of the interaction between the four tested heat-resisting alloys (Inconels 625 and 718, Hastelloy X, stainless steel 410) and nickel-based liquid filler metal Palnicro 36M containing significant amount of palladium addition.

Microscopic studies revealed the displacement of interface for the combination of braze metal with both Inconel 718 and stainless steel 410. The shift of interface location in regard to its original position in the course of phase interaction in brazing temperature indicates the dissolution of mentioned substrate material in the liquid. In the case of Inconel 625 and Hastelloy $X$ such phenomenon is not noticeable for typical brazing parameters $\left(995^{\circ} \mathrm{C}, 10 \mathrm{~min}\right)$. 
An increased content of chromium and molybdenum was observed in the interstitial zones in the joints of all tested nickel superalloys with Palnicro 36M. Niobium acted also as an active agent during the formation of joints. In the case of stainless steel 410 substrate, transition zone is composed of chromium and iron. In all variants the nickel content decreased in the transition zone whereas palladium was uniformly distributed in the bulk of filler metal.

Conflicts of Interest: The authors declare no conflict of interest.

Author Contributions: conceptualization M.B. and J.S., methodology M.B. and J.S.; investigation M.B.; discussion M.B. and J.S., writing - original draft preparation M.B. and editing J.S.

\section{References}

[1] Riabinkin A., Brazing with (NiCoCr)-B-Si amorphous brazing filler metals: alloys, processing, joint structure, properties, applications. METGLAS® Solutions, USA. [yperlink]

[2] Dul I., Zastosowanie i przetwarzanie stopów niklu w przemyśle lotniczym, Welding Technology Review, 2009, Vol. 81(7-8), 67-73.

[3] Pollock T.M., Alloy design for aircraft engines, Nature Materials, 2016, Vol. 15(8), 809-815. [CrossRef]

[4] Davis J.R., ASM Specialty Handbook: Nickel, Cobalt, and Their Alloys, ASM International, Russell Township, 2000.

[5] Babul T., Kondej A., Kowalski S., Baranowski M., Lankiewicz K., Wpływ obróbki powierzchniowej na lutowność stali 410. Welding Technology Review, 2016, Vol. 88(3), 14-18. [CrossRef]

[6] Baranowski M., Jakubowski J., Lutowność wybranych nadstopów niklu, Welding Technology Review, 2014, Vol. 86(7), 3-8. [CrossRef]

[7] Lankiewicz K., Baranowski M., Babul T., Kowalski S., The Study of the Impact of Surface Preparation Methods of Inconel 625 and 718 Nickel-Base Alloys on Wettability by BNi-2 and BNi-3 Brazing Filler Metals, Archives of Metallurgy and Materials, 2015, Vol. 60(1), 159-165. DOI: 10.1515/amm-2015-0025 [ Hyperlink]

[8] Baranowski J., Lutowanie twarde w wybranych zastosowaniach w produkcji lotniczej, Welding Technology Review, 2016, Vol. 88(9), 25-28. [CrossRef]

[9] Bose D., Datta A., Rabinkin A., De Cristofaro N.J., High Strength Nickel-Palladium-Chromium Brazing Alloys, Welding Journal, 1986, Vol. 65(1), 23-30.

[10] Dul I., Senkara J., Bober M., Jakubowski J., Wpływ wysokotemperaturowego wygrzewania próżniowego na lutowność Inconelu 718 lutem Palnicro 36, Welding Technology Review, 2013, Vol. 85(9), 15-19. [CrossRef]

[11] Baranowski M., Bober M., Kudyba A., Sobczak N., The Effect of Surface Condition on Wetting of HASTELLOY® X by Brazing Filler Metal of Ni-Pd-Cr-B-Si System, Journal of Materials Engineering and Performance, 2019, Vol. 28(7), 3950-3959. [CrossRef]

[12] www.espimetals.com

[13] www.azom.com

[14] www.morganadvancedmaterials.com

(C) 2019 by the authors. Submitted for possible open access publication under the terms and conditions of the Creative Commons Attribution (CC BY) license (http://creativecommons.org/licenses/by/4.0/). 